\title{
The Relationship between Employment and Pension Insurance and Its Influencing Factors
}

\author{
Youmei Wang \\ Institute of Commercial Economics \\ Harbin University of Commerce \\ Harbin, P. R. China \\ 28638966@qq.com
}

\author{
Wei Wang \\ School of Finance and Public Administration \\ Harbin University of Commerce \\ Harbin, P. R. China \\ 63993022@qq.com
}

\begin{abstract}
Employment is the basic means of worker's survival, is an important source of social wealth, and is the bas is for social stability and growing presence. Pension insurance is a guarantee of better employment and an important part of entering the aging society. Between employment and pension, there are relationships of mutual restraint, mutual influence, and interaction. On the basis of theoretical and empirical analysis, in order to better promote employment and coordinated development of pension insurance, we should explore the relationship between employment and pension insurance, analysis the factors impacting employment and pension from both macro and micro levels, and put forward suggestions for pension promote employment, such as developing a policy to enable full employment, focusing on a comprehensive assessment of employment and pension insurance, and strengthening the advice interaction between employment and pension policy in their development process.
\end{abstract}

Keywords-employment; pension insurance; relationship; influencing factor

\section{INTRODUCTION}

China is the most populous country in the globe and its total population is keep growing all these years, so the employment problem is becoming increasingly apparent. Actually, employment and pension insurance are difficult to divide from the overall social policy; they are the two aspects of the overall problem of promoting social-economic coordination and stabling development. With the continuous economic and social development, for national purposes, the basic livelihood issues are having job, having income and having the sense of security. For our current, whether it is to promote employment or improve the pension system are urgent problems. We need to analyze and study more effective ways from a professional and scientific point of view, to find a causal relationship between them, solve real widespread social problem.

British economist John Maynard Keynes discovered flaws in the market, as a major aspect of the labor force, in order to avoid significant changes in the economy; he wanted to make use of government to improve the situation. However, that idea only noted the impact of changes in total demand for total employment, failed to notice the structural changes occurred in employment itself. Thus, Supply-siders held a negative attitude to Keynes "lack of effective demand" theory. Arthur Laffer made its negation and emphasized on the impact of supply side to produce full employment, thereby achieving full employment status. The rational school of thought natural rate of unemployment and a certain rational judgment should be taken seriously enough. Lucas and some of them believe that labor supply and wages of employees rational judgment has important relevance. In Keynes' theory, there are 3 reasons to explain why the demands of the labor market are always lower than the state of the labor market supply, they are: diminishing marginal propensity to consume, diminishing marginal efficiency of capital and liquidity preference. Government must reform policies, abandon the original policy, adopted a proactive fiscal policy and monetary policy. This will ensure promotion demand, and reach a state of equilibrium between demand and labor supply at a certain level.

Full employment, which pointed by Keynes in his book, The General Theory of Employment, Interest and Money, means when the wage below a certain level, all people who willing to accept work can have a job. Economist Friedman said the unemployment rate in this state as natural rate of unemployment, research scholars at this time feel that if the natural rate of unemployment is $2 \%-3 \%$ is reached a state of full employment, along with the 20th Century after the mid1970 s, evolving economic and technological, the natural rate of unemployment full employment level reached about 5\%. Currently, a considerable part of the developed countries to some developing countries regard the achievement of full employment as an important goal of economic development of the country. Full employment can be seen as an ideal state of economics, refers to all willing to accept the prevailing wage level job seekers can find a job. However, this state can't be fully realized, because even reached a state of full employment, also due to insufficient information and other reasons, and produce structural unemployment and frictional unemployment. We can be certain that the full employment and small-scale unemployment coexist as in [1], [2]. Natural rate of unemployment in each country is different, countries from contact to determine their actual situation has not reached full employment status. In 1970s, US natural rate of unemployment rose slightly to $4.5-5.5 \%$, we can say at this time if the US labor population reached $94.5-95.5 \%$ employment rate is to reach full employment. In 2013, the registered urban unemployment rate of china was $4 \%$, it can be said that if the country has reached 96 percent of the labor force employment rate is to reach full employment status. 
Pension insurance is the objective of social development, within the scope of social income distribution policy, promotion of employment as the macroeconomic objectives, content belong economic growth policies. The relationship between pension and employment is very close; pension for modern society, the labor market has to be small. Getting older of employees can be seen as a risk in the labor market, and pension insurance is precisely the most effective means of modern society avoid this risk, it eliminates the worries of employees and allows them to work safely as in [3], [4].

There are high and general levels of pension insurance. Pension should a sum of cash flow which fixed as long as the lifetime of insured person, which can provide the insured person to pay stable and sufficiently after exiting areas of work. Insured persons can use these funds to obtain various equipped good living environment, the funds can also make the insured enjoy first-class pension services, as well as plenty of parts to enhance their quality of life and quality of spiritual life pension, which reached a relatively high level of quality of old-age insurance.

The general level of pension is just meeting the minimum standard pension payment standards, there is no surplus state. In every aspect of life, the general level of pension can't match and a high level of pension insurance, the insured person can't enjoy a good old age and living environment in such an environment, can only provide a stable and reliable for the insured person sources of livelihood as in [5].

Paying attention to the status of implementation of the pension system in recent years, although cities are expanding their pension coverage, but the effect of execution did not seem very good. Pension insurance personnel failed to pay on time, the payment period did not meet the legal age, decreased level of individual contributions, all the situations mentioned above are the negative effects of the development of old-age insurance as in [6]. Employment levels in most parts of grow fairly slowly that can't play a positive role to promote pension. Currently pension insurance personnel is still growing, but if it reaches a certain amount, the data will be leveled off, the cumulative surplus for urban workers in basic pension insurance will not increase, this will give China's financial enormous pressure.

\section{FACTORS ANALYSIS OF EMPLOYMENT AND PENSION INSURANCE}

There are both macroeconomic factors and micro factors affecting employment and pension insurance. Macro factors mainly include economic factors and demographic factors.

\section{A. Economic factors}

With the rapid growth of Chinese economy, high unemployment inevitably exists. The quality of the labor employment situation directly affects the development of China's economy, while economic development also affects the balance of supply and demand in the labor market. Enterprise expand the unit labor standards to recruit more staff in order to increase production, to better meet the social demand for the product. The economic development of the country or region better, the need for workers will be higher, and then it can achieve a higher level of employment. To the opposite, a weak economic development of the country or region will reduce the need for workers, in this situation, companies can't provide surplus labor, and then the unemployment rate will increase. Since the reform and opening up, China's industrial structure change to make employment structure will be changed, change the structure of employment has led to pension structure has also undergone a transformation. According to "Petty-Clark Principle" discussed for the employment structure, the proportion of primary industry employment in the labor force showed a gradual downward trend; the ratio of the second and third industry employment continues to increase.

\section{B. Demographic factors}

Demographic factors can change the balance of supply and demand in the labor market. Demographic mainly includes population of gender, population age and quality of the population and so on. Men willingness to participate in pension insurance compared to women stronger, mainly due to the different responsibilities of men and women in the social division of labor; meanwhile, women more strongly depend on their children, and tend to be more family pension concept. It will impact the development of employment as well if young people occupy heavily in the whole state's population. Improve population quality can improve the actual living standards of the people; we can make a better pension and economic development of linkages and development.

Micro economic factors include pension funds, employment and pension insurance rate.

\section{A. Pension fund}

Pension fund refers to funds of enterprises and individuals in accordance with the relevant laws and regulations to pay a certain proportion of the social pension insurance pension plan accumulation form, it is the variety of pension schemes for the payment of current and expected pension debt savings fund. At present, China's pension fund is mainly composed of two parts, one of them is social endowment insurance forced by social endowment insurance, the other part is a personal pension fund other pension plan formation as in [7]. For example, the increased trend of pension fund in Heilongjiang province in China is as shown in Fig .1. In the figure, the first bar represents pension fund income, the second bar is expenditure, and the third bar is cumulative balance.

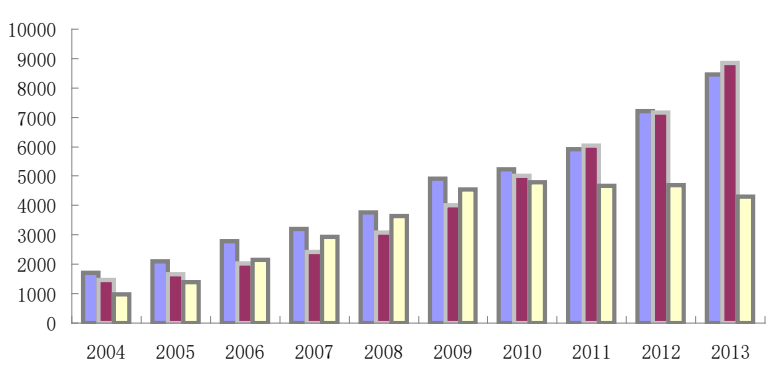

Fig. 1. Pension fund in Heilongjiang province from 2004 to 2013. 


\section{B. Employmentrate}

Employment rate refers to the percentage of the total employed population and the population aged 16 and over. At the expiry of a specified period of time limit of age, you have a job and get paid or benefits; or have positions temporarily without a job; and unpaid workers in family businesses or farms, are calculated as of the employed population. Economic growth and full employment are the two main goals of macroeconomic, they relate to the economy healthy, stable operation and development in China. Traditional economic theory holds that the most direct and effective way to solve the unemployment is driven by employment growth by improving economic growth, thereby increasing employment rate and reduce unemployment as in [8], [9], [10]. According to national statistics, in 2012, the number of urban employment was 5642.7 million, the number of registered jobless urbanites was 917 million people, and the urban employment rate was $86.02 \%$. While in 2012, the registered urban unemployment rate was $4.1 \%$. So, increasing employment rate would be the most direct way to realize full employment as soon as possible. In 2013, the Chinese workers reached 769770 thousand people, of which 382400 thousand were in urban, accounting for 49.7\% as shown in Fig. 2, 387370 thousand were in village, accounting for 50.3\%. From 2004 to 2013, the increase is a total of 27130 thousand employees in China, the average annual increase of 3010 thousand people.

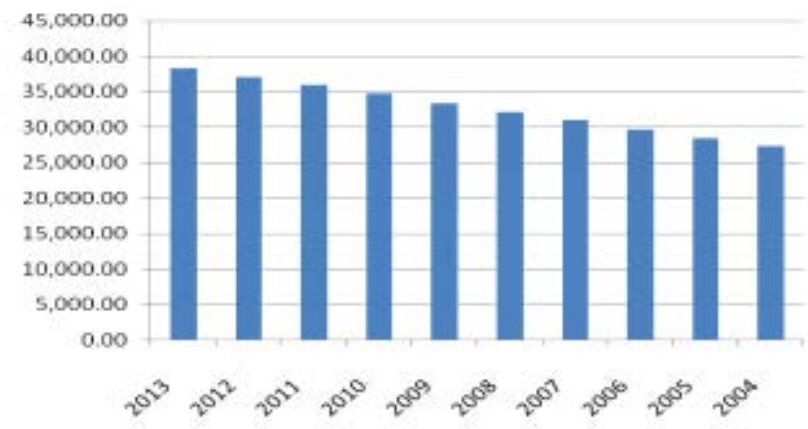

Fig. 2. Employees in urban from 2004 to 2013.

\section{Pension insurance rate}

China's current social security system is changing the binary division of urban and rural areas, and rural social security system is not perfect. The transfer of rural surplus labor force means that no part of the population from the pension insurance becomes progressively be covered by the pension system. China's pension insurance implements tripartite pension burden principle, this system determines the rights and enjoy pension benefits are directly related to the employment situation. Therefore, urbanization and employment rates are important factors affecting both the rate of pension insurance can’t be ignored.

\section{SUGGESTIONS TO IMPROVE THE PROMOTION OF EMPLOYMENT FOR PENSION EFFECTS}

In the development process of China's labor force employment and pension insurance policies, the starting point should be coordinated and balanced development of both parties and make them play their roles to maximize.

It is necessary to define two policies' own characteristics and their development direction, but also to avoid the detachment or conflict between them. In order to make the comprehensive utility of employment and pension policies play better roles, it is important to adjust the gaps among different provinces' promotions of employment and pension insurance as in [11]. Therefore, in order to achieve the full economic and social progress much better and sooner, this paper will try to put forward some suggestions to improve the promotion of employment for pension effects.

\section{A. Developing a policy to enable full employment}

In recent years, China's unemployment rate is showing an increasing trend, but the economic growth rate was not affected This phenomena shows that there is space for adjusting China's industrial structure. Hence, Chinese government should take strong administrative measures, develop a good employment macroeconomic policy to help all kinds of people, and make more workers employments. Moreover, the government should also balance employment and income distributions for protecting the legitimate rights and interests of various types of labor groups, especially low-income groups. Apart from this, it is important to guide the distribution system in different ownership enterprises uniformly and fairly. In other words, it would be beneficial to encourage employment of workers to non-public enterprises, so that the labor mobility can be balanced and different qualities of talent can play capability.

\section{B. Focusing on a comprehensive assessment of employment and pension insurance}

Before China's employment and pension policies, there should be methods such as expert advice and public opinion to assess the policy comprehensively. If those kinds of method can be done, the problem of theory out of practice in implementation would be avoided. Furthermore, it would be better to focus on the pursuit of the combined effect. As a new policy, its single-effect may not be ideal, but through it the relationship between employment and pension insurance can be better coordinated and the best combined effect of state can be achieved.

\section{Strengthening the advice interaction between employment and pension policy in their development process}

Maintaining positive interaction between employment and pension insurance ask both parties take full account of each other policies implementation problems, cleverly avoid problems and achieve win-win situation. Adding this link does not affect the functional organizations of their own policymaking initiative, to the opposite, it would help to eliminate the adverse consequences in advance. Hence, in the development process of employment and pension policy, it would be fairly 
helpful and necessary for functional organizations to solicit opinions to each other.

\section{ACKNOWLEDGMENT}

This work is supported by Humanities and Social Sciences Fund of Ministry of Education under grant 12YJC790190, National Social Sciences Fund under grant 13AZD071, Young Academic Backbone Support Program under grant 1253G029, Postdoctoral Scientific Research Initiation under grant LBHQ14094, Economic Social Development Project under grant 15011 in Heilongjiang Province in China.

\section{REFERENCES}

[1] Li Hong, Full employment policy and unemployment governance and revelation, Journal of Jiang xi University of Finance and Workers, vol.10, 2006.(in Chinese)

[2] Huang Dongmei, Full emp loyment, economic growth and the role of the government to explore the role, Theoretical Inquiry, vol.11, 2009.(in Chinese)
[3] Liu Jing, Research on the interactive relationship between employment and social security, Shanghai: Fudan University Press, 2003.(in Chinese)

[4] Li Haiping, On the impact of China's current pension insurance system on employment, Nanning: Guangxi University Press, 2007.(in Chinese)

[5] Li Zhenzhen, Study on the system of the old age insurance system in urban and rural areas and urban and rural planning, Shanghai: Fudan University Press, 2010.(in Chinese)

[6] Yuan Lihui, Research on the integration of pension insurance system, Kunming: Yunnan University Press, 2012.(in Chinese)

[7] Yan Jun, China's new rural social endowment insurance system research, Beijing: Beijing Forestry University Press, 2010.(in Chinese)

[8] Narenyuya, Relationship between employment and Naren, Endowment insurance policy and interaction mechanism,. Journal of Inner Mongolia Finance and Economics College, vol. 6, 2004.

[9] Caihong, Discuss how to improve our flexible employment pension insurance system, Economic Management, vol.12, 2013.(in Chinese)

[10] Yin Wenyao, The development of flexible employment in China and the impact on social pension insurance, Journal of Zhejiang University, vol.7, 2009.(in Chinese)

[11] Wu Xiangling. The lack of basic endowment insurance policies in China and the choice, Journal of Huazhong Normal University, vol.5, 2010.(in Chinese) 